\title{
Influence of some biologically active substances on amount of MGMT and MARP proteins in human cells in vitro
}

\author{
K. V. Kotsarenko ${ }^{1}$, V. V. Lylo ${ }^{1}$, L. L. Macewicz ${ }^{1}$, T. P. Ruban ${ }^{1}$, \\ Yu. S. Luchakivska ${ }^{2}$, M. V. Kuchuk², L. L. Lukash ${ }^{1}$ \\ ${ }^{1}$ Institute of Molecular Biology and Genetics, NAS of Ukraine \\ 150, Akademika Zabolotnoho Str., Kyiv, Ukraine, 03680 \\ ${ }^{2}$ Institute of Cell Biology and Genetic Engineering, NAS of Ukraine \\ 148, Akademika Zabolotnoho Str., Kyiv, Ukraine, 03680 \\ lukash@imbg.org.ua
}

\begin{abstract}
Aim. To investigate an effect of biologically active compounds IFN- $\alpha 2 b$, EMAPII, Card medium, fibronectin on the amount of MGMT (O'-methylguanine-DNA methyltransferase) and MARP (anti-Methyltransferase Antibo$d y$ Recognizable Protein) proteins in human cells in vitro. Methods. The human cells of $4 B L, H e p-2$ and AlO2 lines were treated with growth factors and cytokines. Changes in the amount of MGMT and MARP proteins were studied by Western blot analysis with anti-MGMT mAbs. Results. The treatment of A102 cells with EMAPII, fibronectin, Laferon and Card medium led to a decreased level of the MGMT protein, whereas the amount of MARP was highly increased in these cells. The treatment with the recombinant protein IFN- $\alpha 2 b$ increased the amount of MGMT and MARP proteins in Hep-2 cells. The treatment with extracts of transgenic plants, containing human IFN- $\alpha 2 b$, caused a significant decrease in the content of both proteins in Hep-2 cells and MARP in 4BL cells. Conclusions. Both MGMT and MARP are highly inducible proteins. Their amount in cells can be changed by some growth factors (Card medium, fibronectin), cytokine (IFN- $\alpha 2 b$ ), cytokine-like (EMAPII) or cytokine-containing substances (Laferon and IFN- $\alpha 2 b$ in plant extracts). This regulation depended not only on the type of biologically active substances but on the cell line used in this study as well.
\end{abstract}

Keywords: human cell lines, repair enzyme MGMT, MARP, cytokines, growth factors, Western blot analysis.

Introduction. The repair enzyme $\mathrm{O}^{6}$-methylguanineDNA methyltransferase (MGMT) removes alkyl adducts from the $\mathrm{O}^{6}$-position of guanine in DNA. It is the major defense factor against the mutagenic, carcinogenic and cytotoxic effects of alkylating agents $[1,2]$. MGMT protects both normal cells from endogenous and exogenous carcinogens and tumor cells from chemotherapeutic alkylating compounds. Therefore, this enzyme is considered to be one of the targets to regulate antitumor efficacy of the alkylating agents [3].

According to the literature data the expression of $M G M T$ gene may be affected by various factors: the al-

(c) Institute of Molecular Biology and Genetics, NAS of Ukraine, 2014 kylating agents, single-strand DNA breaks, transcription factors, activators of protein kinase $\mathrm{C}$, the $M G M T$ gene promoter hypermethylation, $\mathrm{p} 53$ protein etc. [4, 5]. There are some works where cytokines have been also shown to be able to influence the MGMT gene expression. For example, IFN- $\beta$ decreased the MGMT gene expression in human glioma and neuroblastoma cells in vitro and increased the sensitivity of these cells to the antitumor alkylating agent temozolomide [6, 7]. IL-24 also reduced the level of the $M G M T$ gene expression in the human melanoma cells in dose-dependent manner [8]. A combined action of two cytokines IL- $1 \beta$ and IFN$\gamma$ increased the level of this gene expression in the rat $\beta$ cells in vitro [9]. Nowadays, application of regulation 
of the MGMT gene expression with some cytokines is launched in clinical practice. Complex treatment of the patients, who had newly diagnosed primary glioblastoma multiforme, with cytokine IFN- $\beta$ and temozolomide has resulted in favorable outcome, particularly in cases when the tumor cells contained the unmethylated MGMT promoter [10]. So the combined action of cytokines, which reduced the level of $M G M T$ gene expression, and antitumor alkylating agents improves their efficiency in both cell lines and humans.

The aim of our study was to investigate the effect of biologically active compounds such as IFN- $\alpha 2 b$, EMAP II, Card medium, fibronectin, on the amount of MGMT and MARP proteins in the human cells in vitro.

Recombinant interferon $\alpha 2 b$ (IFN- $\alpha 2 b$ ) is widely used in oncology due to its well-known antitumor activity [11]. Endothelial-monocyte activating polypeptide II (EMAP II), whose properties are not completely understood, also exhibits the anticancer activity [12]. Since the $M G M T$ gene expression is known to change during cell differentiation [13], such factors as Card medium, ATP and fibronectin, which take part in the process of cell differentiation, were also investigated in this study.

Biological properties of the substances mentioned above have been known for a long time, but their possible role in regulation of the MGMT gene expression has not been studied yet.

Materials and methods. The following human cells were used in this study: 4BL - fibroblast-like cell line derived in our laboratory [14], standard Hep-2 cell line (laryngeal cancer) and A102 cell line (skin fibroblasts), kindly provided by Prof. McCormick (Michigan State University, The United States).

The cells were cultivated in standard DMEM («PAA», USA) with $10 \%$ FBS («Sigma», USA) and antibiotics penicillin $(0.02 \%)$ and streptomycin $(0.02 \%)$ at $37{ }^{\circ} \mathrm{C}$ with $4 \% \mathrm{CO}_{2}$.

Different commercial and non-commercial biologically active substances were used. IFN- $\alpha 2 b$ was used as purified recombinant protein («Interpharmbiotek», Ukraine), in the form of commercial Laferon preparation («Interpharmbiotek») and as a component of the crude extract of transgenic carrot plants (Daucus caro$t a$ L., Nantskaya and Perfektsiya varieties). The transgenic carrot plants expressing IFN- $\alpha 2 \mathrm{~b}$ were obtained via
Agrobacterium tumefaciens-mediated transformation using two vector constructs containing: i) the sequences encoding interferon gene fused with Nicotiana plumbagenifolia calreticulin apoplast targeting signal driven by $35 \mathrm{~S} \mathrm{CaMV}$ promoter and selective neomycin phosphotransferase II (nptII) gene in order to obtain the transgenic carrot plants able to accumulate human IFN- $\alpha 2 b$ protein; ii) the sequence encoding gus $A$ gene driven by $35 \mathrm{~S} \mathrm{CaMV}$ promoter and the selective nptII gene for obtaining the transgenic carrot plants that we used as control ones in our study - so-called «empty» vector. According to the previous studies the transgenic carrot plants were characterized by high level of the recombinant human IFN- $\alpha 2 b$ protein accumulation. The protein extracts of these plants were characterized by a high antiviral activity [15].

The purified recombinant protein EMAPII was kindly provided by Prof. A. I. Korneluk (IMBG, Ukraine). «Card differentiating» medium supplemented with growth factors of different origin was developed and used in our laboratory for the differentiation of stem cells into cardiomyocytes [16]. The commercial preparations Fibronectin and ATP were received from «Sigma».

We used the chemical agents 5-azacytidine and mitomycin C. The conditions of cell treatment with the biologically active substances in the serum-free culture medium were described previously [17].

Cell lysates were prepared according to [18]. SDSPAGE $(12 \%$ gel) was performed using Laemmli method [19]. The concentration of total protein in cell lysates was measured colorimetrically according to Bradford method [20].

Monoclonal anti-MGMT antibodies (clone 23.2, isotype Ig G2b) were obtained from Novus Biologicals (USA), secondary antibodies conjugated with horseradish peroxidase were obtained from «Sigma». The procedure of MGMT identification in the samples was performed by Western blot analysis according to the methodological instructions of the manufacturer of monoclonal antibodies (http://www.novusbio.com/ support/ protocols/protocol-specific-for-mgmt-antibody-nb100168.html). Densitometry of stained membranes by ScionImage 4.0.2 and Origin 8.1 programs was used as loading control $[21,22]$.

Results and discussion. The human MGMT protein was shown to have molecular weight of $22-24 \mathrm{kDa}$ 


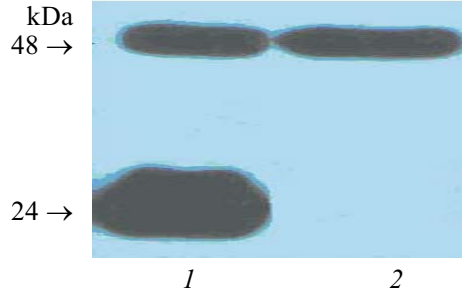

Fig. 1. Western blot analysis of $M G M T$ gene expression in cells Hep-2 (1) and 4BL (2)

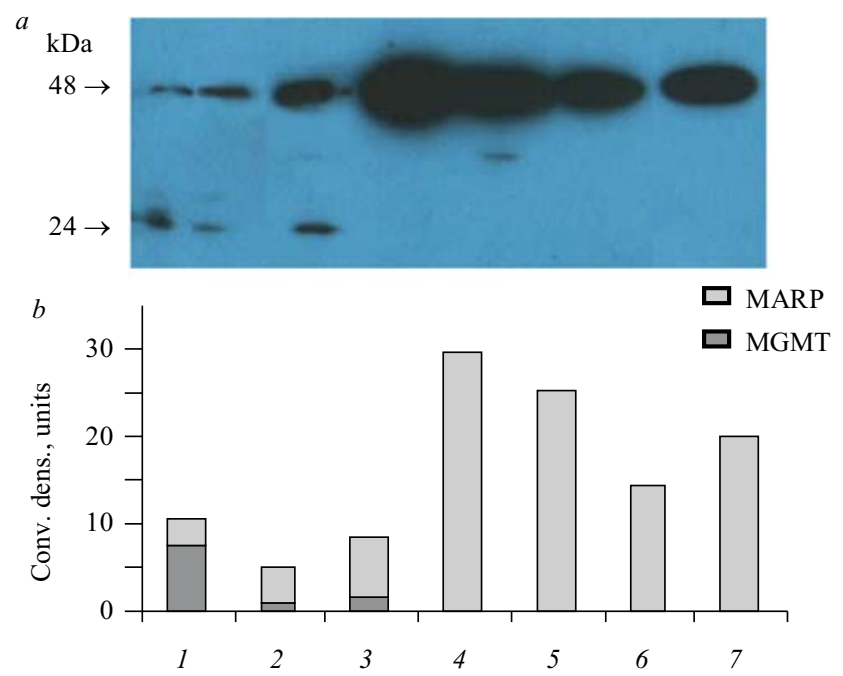

Fig. 2. Effect of different biologically active substances on the amount of MGMT and MARP proteins in A102 cells: $a$ - Western blot analysis (1 - Hep-2, positive control; 2 - A102- control; 3 - A102 + ATP (20 $\mu \mathrm{g} / \mathrm{ml}) ; 4-\mathrm{A} 102+$ Card medium; 5 - A102 + EMAP II $(10 \mu \mathrm{g} / \mathrm{ml}) ; 6-$ A102 + Laferon $(20 \mathrm{IU} / \mathrm{ml}) ; 7$ - A102 + fibronectin $(10 \mu \mathrm{g} / \mathrm{ml})) ; b-$ results of densitometry. The vertical line represents the level of MGMT and MARP proteins amount in conventional densitometry units

[1]. However, the Western blot analysis with monoclonal anti-MGMT antibodies (clone 23.2) revealed two highly specific immunoreactive bands $-24 \mathrm{kDa}$ (classic MGMT protein) and $48 \mathrm{kDa}$ (anti-Methyltransferase Antibody Recognizable Protein or MARP) (Fig. 1). It should be noted that in our previous works MARP was named as a modified form of MGMT, while the classic $24 \mathrm{kDa}$ protein was named as an unmodified form of MGMT [17, 23]. We proposed several hypotheses about the nature of MARP, namely, post-translation modifications, dimerization of MGMT, etc., which have been discussed in the mentioned articles. So far there is an open question regarding the nature of the $48 \mathrm{kDa}$ protein.

In this work we have compared the effect of various exogenous biologically active substances on the amount of both MGMT and MARP proteins in the human cell lines. The results of the A102 cells treatment with Card medium, EMAPII, Laferon, fibronectin and ATP are shown in the Fig. 2. The treatment of A102 cells with different exogenous factors led to the dramatic changes of the amount of MGMT and MARP proteins. Hep-2 cells were used as positive control in Western blots, because they express both types of proteins (Fig. 1).

Almost all of the studied factors (except ATP) decreased the level of MGMT protein amount in the A102 cells (lanes 4-7) compared with the control A102 cells (lane 2). The treatment with ATP and to a greater extent with Card medium (lane 4), EMAP II (lane 5), Laferon (lane 6) and fibronectin (lane 7) led to an increased amount of MARP.

In this work we studied the influence of purified recombinant protein IFN- $\alpha 2 b$ and the extract of transgenic carrot tissues, expressing human IFN- $\alpha 2 b$, on the levels of MGMT and MARP proteins in Hep-2 and 4BL cell lines.

As shown in Fig. 3, the treatment of Hep-2 cells with the human recombinant protein IFN- $\alpha 2 b$ led to slight increase of the amount of MGMT and MARP proteins (lanes 2 and 3). No significant changes in the amount of MARP were detected in 4BL cells. In contrast to these data, the results presented in Fig. 4 show a significant decrease of the MGMT and MARP proteins amount in Hep-2 cells as well as the MARP amount in 4BL cells after their treatment with the extracts of transgenic plant tissues, expressing human IFN- $\alpha 2 b$. On the other hand the amount of MGMT in Hep-2 cells and MARP in both cell lines did not significantly change after the treatment with the extract of plants without interferon gene.

We suppose that different effects of the purified recombinant protein IFN- $\alpha 2 b$ and the interferon-containing plant extract on the MGMT and MARP proteins amount may be caused by the influence of some plant extract components on the action of interferon.

Thus, the results presented in Fig. 2-4 show that the effect of interferon preparations may differ depending on the composition of these preparations and the type of cell lines. There are several hypotheses about the mechanisms of modulating the $M G M T$ gene expression by cytokines. According to one of them the $\mathrm{p} 53$ protein is involved in regulation of the MGMT transcription by cy- 


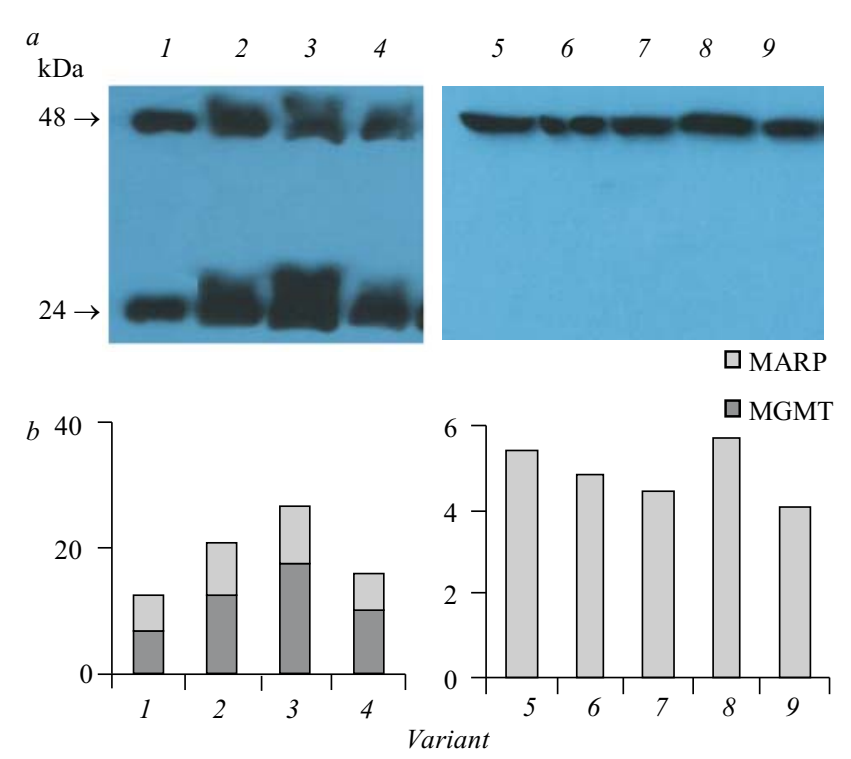

Fig. 3. The effect of purified recombinant protein IFN-a2b on the MGMT and MARP proteins amount in the human cell lines: $a-$ Western blot analysis ( 1 - Hep-2, control; 2 - Hep-2 + IFN-a2b (2000 $\mathrm{IU} / \mathrm{ml}) ; 3$ - Hep-2 + IFN-a2b (200 IU/ml); 4 - Hep-2 + IFN-a2b (2 $\mathrm{IU} / \mathrm{ml}) ; 5$ - 4BL, 182 p., control; 6 - 4BL + IFN-a2b (2000 IU $/ \mathrm{ml}) ; 7$ $4 \mathrm{BL}+\mathrm{IFN}-\mathrm{a} 2 \mathrm{~b}(200 \mathrm{IU} / \mathrm{ml}) ; 8-4 \mathrm{BL}+\mathrm{IFN}-\mathrm{a} 2 \mathrm{~b}(20 \mathrm{IU} / \mathrm{ml}) ; 9-4 \mathrm{BL}+$ IFN-a2b $(2 \mathrm{IU} / \mathrm{ml})) ; b$ - results of densitometry. The vertical line represents the amount of MGMT and MARP proteins in conventional densitometry units

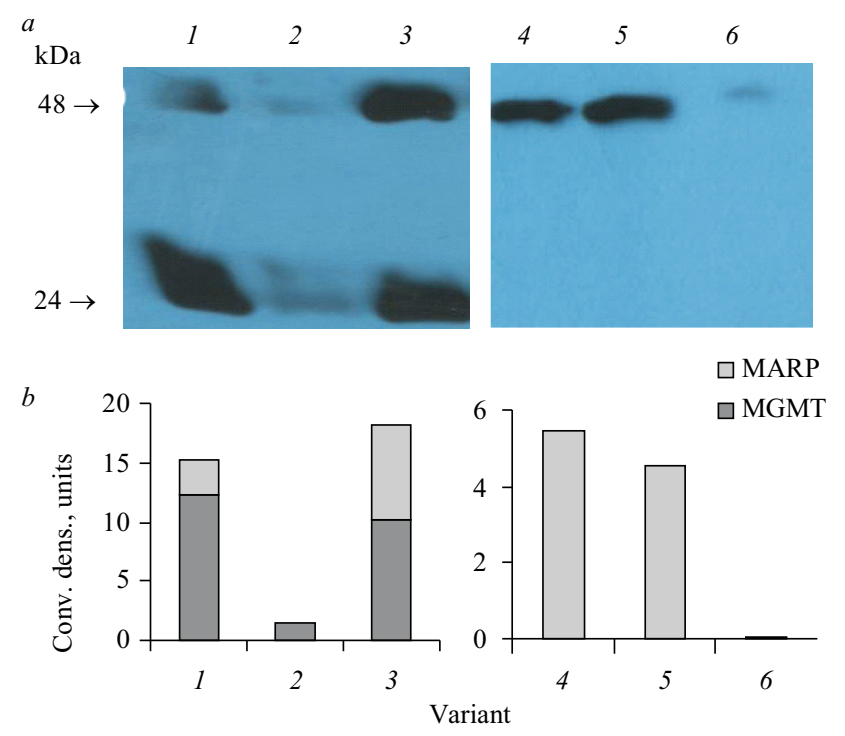

Fig. 4. The effect of extract of transgenic carrot on MGMT and MARP proteins amount in the human cell lines: $a-$ Western blot analysis (Hep2: 1 - control; 2 - extract of transgenic carrot plants, containing human IFN-a2b (600 IU/ml); 3 - extract of transgenic carrot cells transfected with an «empty» vector; 4BL: 4 - 182 p., control; 5 - extract of transgenic carrot cells transfected with an «empty» vector; 6 - extract of transgenic carrot plants, containing human IFN-a2b (600 IU/ml)); $b-$ results of densitometry. The vertical line represents the level of MGMT and MARP proteins in conventional densitometry units

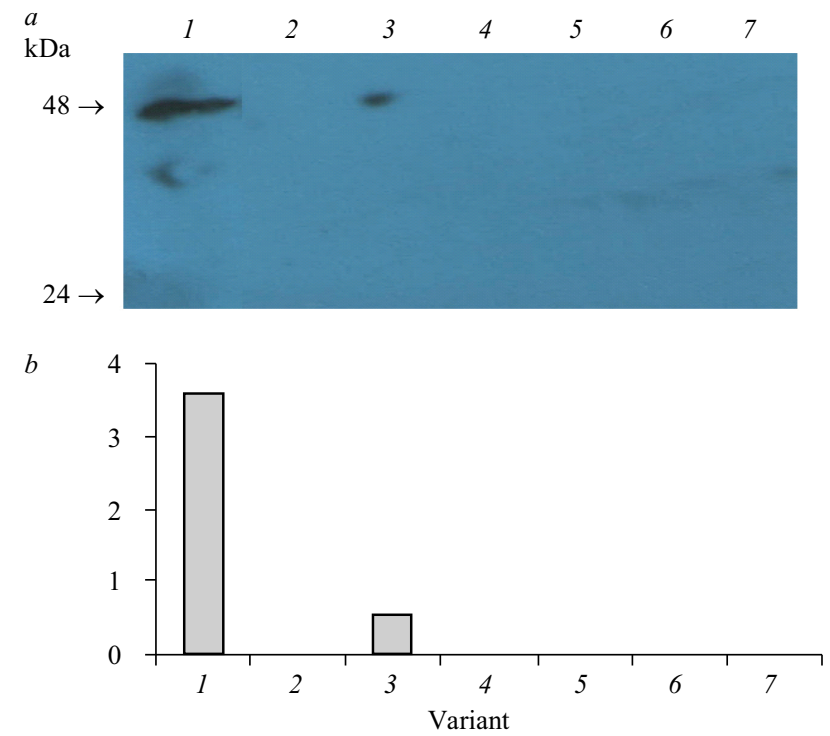

Fig. 5. The effect of 5-azacytidine on the MARP protein amount in the 4BL cells $(180$ p.): $a$ - Western blot analysis $(1-$ control; 2 - mitomycin $\mathrm{C}+5$-aza $(10 \mu \mathrm{g} / \mathrm{ml}), 8 \mathrm{~h} ; 3$ - 5-aza $(1 \mu \mathrm{g} / \mathrm{ml}), 11$ days; 4 - 5-aza (10 $\mu \mathrm{g} / \mathrm{ml}), 6$ days; 5 -5-aza $(10 \mu \mathrm{g} / \mathrm{ml}), 11$ days; 6 - mitomycin $\mathrm{C}+5$-aza $(1$ $\mu \mathrm{g} / \mathrm{ml}), 6$ days; 7 - mitomycin $\mathrm{C}+5$-aza $(10 \mu \mathrm{g} / \mathrm{ml}), 6$ days $) ; b$ - results of densitometry. The vertical line represents the MGMT and MARP proteins amount in conventional densitometry units

tokines $[6,8]$. Another one suggests that the transcriptional factor NF- $\mathrm{KB}$ is activated by cytokines and affects the transcription of target genes including MGMT [24, $25]$. We plan to continue our research of involving these transcriptional factors in regulation of the MGMT gene expression under the influence of the studied cytokines.

We presume that the gene encoding MARP protein does not belong to the housekeeping genes because its expression can be regulated by various exogenous factors. The Hep-2 cells usually have both proteins (Fig. 1, lane 1) as well as the 4BL cells in early passages [26]. However, after prolonged cultivation (more than 130 passages) the 4BL cells have lost the conventional MGMT protein (Fig. 1, lane 2). According to the literature data, hypermethylation of the MGMT gene promoter commonly occurs causing a gene silencing in both different cell lines and human cells in vivo $[1,5,10]$. Therefore in our experiments 5-azacytidine was selected as a demethylating agent that can affect the $M G M T$ gene expression in the MGMT-deficient 4BL cells (Fig. 5). 5azacytidine was the first identified demethylating agent that inhibits DNA methyltransferases and reverses DNA hypermethylation, restoring the expression of silenced genes [27]. The mechanisms involved in the 5-azacyti- 
dine cytotoxic effects include inhibiting DNA, RNA and protein synthesis, drug incorporation into DNA and RNA, as well as the activation of DNA damage pathways. Since the non-proliferating cells are practically insensitive to azacytidine [28], mitomycin C was used in this study as a cytostatic agent for the inhibition of cell proliferation [29].

As shown in Fig. 5, the treatment of 4BL cells with 5 -azacytidine alone or in the combination with mitomycin C did not influence the MGMT protein amount. These results may indicate that the absence of the conventional MGMT protein in the 4BL cells is not associated with the promotor hypermethylation. However, the MARP amount significantly changed under the 5azacytidine alone or in combination with mitomycin $\mathrm{C}$ treatment. This fact requires further investigation.

Conclusions. Monoclonal anti-MGMT antibodies (clone 23.2) recognize both the MGMT protein (M. w. $\sim 24 \mathrm{kDa}$ ) and the unknown protein (M. w. $\sim 48 \mathrm{kDa}$ ), named as MARP, in Western blot analysis. These proteins are highly inducible and their amount can be changed by some growth factors (Card medium, fibronectin), cytokine (IFN- $\alpha 2 b)$, cytokine-like (EMAP II) or cytokine-containing substances (Laferon and IFN- $\alpha 2 b$ in plant extracts). However, this regulation depends not only on the type of biologically active substances but on the type of cell lines. The absence of MGMT protein in 4BL cells is unlikely due to the $M G M T$ gene promotor hypermethylation. The mechanisms of regulation of the $M G M T$ gene expression by growth factors and cytokines require further studies.

К. В. Коцаренко, В. В. Лило, Л. Л. Мацевич, Т. П. Рубан,

Ю. С. Лучаківська, М. В. Кучук, Л. Л. Лукаш

Вплив деяких біологічно активних речовин на вміст білків MGMT і MARP у клітинах людини in vitro

Резюме

Мета. Дослідження впливу біологічно активних сполук IFN- $\alpha 2 b$, EMAPII, середовища Card і фібронектину на вміст білків MGMT (O'-метилгуанін-ДНК метилтрансфераза) і MARP (білок, щчо розпізнається анти-MGMT антитілами) у клітинах людини іn vitro. Методи. Клітини людини ліній 4BL, Нер-2 і А102 обробляли ростовими факторами і цичтокінами. Зміни в кількості білків MGMT i MARP досліджували з використанням Вестерн блот аналізу і моноклональних анти-MGMT антитіл. Результати. Обробка клітин А102 препаратами ЕМАРІІ, фібронектину $і$ Лаферону призводить до зниження кількості білка MGMT на фоні значного зростання кількості білка MARP у циих клітинах. Обробка рекомбінантним білком IFN- $\alpha 2 b$ підвищує кількість білків MGMT i MARP у клітинах Нер-2, а екстрактами трансгенних рослин, які містять

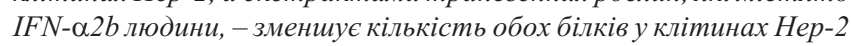
mа білка MARP у клітинах 4BL. Висновки. MGMT i MARP є високоіндуцибельними білками. Їхня кількість може варіювати під дією деяких ростових факторів (середовище Саrd і фібронектин), ии-

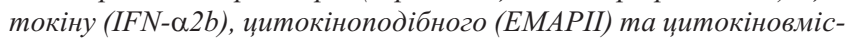
них (Лаферон і IFN- $\alpha 2 b$ у композииї з рослинними екстрактами) препаратів. Виявлена регуляція залежить не лите від типу біологічно активних речовин, але й від клітинних ліній, використаних в експериментах.

Ключові слова: лінії клітин людини, репаративний фермент MGMT, MARP, цитокіни, ростові фактори, Вестерн-блот аналіз.

Е. В. Коцаренко, В. В. Лыло, Л. Л. Мацевич, Т. А. Рубан, Ю. С. Лучакивская, Н. В. Кучук, Л. Л. Лукаш

Влияние некоторых биологически активных веществ на содержание белков MGMT и MARP в клетках человека in vitro

Резюме

Цель. Исследовать влияние биологически активных соединений

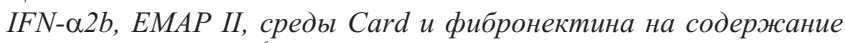
белков MGMT (O'-метилгуанин-ДНК метилтрансфераза) $u$ MARP (белок, распознаваемый анти-MGMT антителами) в клетках человека in vitro. Методы. Клетки человека линий $4 B L$, Нер-2 и А102 обрабатывали ростовыми факторами и циитокинами. Изменения в количестве белков MGMT и MARP исследовали с использованием Вестерн блот анализа и моноклональных антиMGMT антител. Результаты. Обработка клеток А102 препаратами ЕМАРІІ, фибронектина, Лаферона и средь Сагd снижает количество белка MGMT на фоне значительного возрастания количества белка MARP в этих клетках. Обработка рекомбинант-

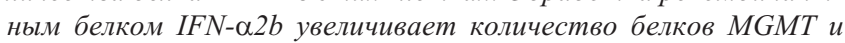
MARP в клетках Нер-2, а экстрактами трансгенных растений, содержащих человеческий IFN- $\alpha 2 b$, - существенно снижает количество обоих белков в клетках Нер-2 и MARP в клетках $4 B L$. Выводы. MGMT и MARP являются высокоиндуцибельными белками. Их количество может варьировать под действием некотоpых ростовых факторов (среда Сагd и фибронектин), иитокина

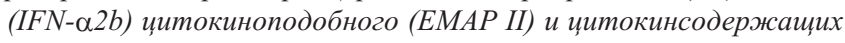
(Лаферон и IFN- $\alpha 2 b$ в композиции с растительньли экстрактами) препаратов. Выявленная регуляция зависит не только от типа биологически активных веществ, но и от клеточных линий, использованных в экспериментах.

Ключевые слова: линии клеток человека, репаративный фермент MGMT, MARP, ичитокины, ростовые факторы, Вестернблот анализ.

\section{REFERENCES}

1. Pegg AE. Multifaceted roles of alkyltransferase and related proteins in DNA repair, DNA damage, resistance to chemotherapy, and research tools. Chem Res Toxicol. 2011;24(5):618-39.

2. Gerson SL. MGMT: its role in cancer aetiology and cancer therapeutics. Nat Rev Cancer. 2004;4(4):296-307.

3. Christmann M, Kaina B. Transcriptional regulation of human DNA repair genes following genotoxic stress: trigger mechanisms, inducible responses and genotoxic adaptation. Nucleic Acids Res. 2013;41(18):8403-20.

4. Natsume A, Ishii D, Wakabayashi T, Tsuno T, Hatano H, Mizuno $M$, Yoshida J. IFN-beta down-regulates the expression of DNA 
repair gene $M G M T$ and sensitizes resistant glioma cells to temozolomide. Cancer Res. 2005;65(17):7573-9

5. Kaina B, Christmann $M$, Naumann $S$, Roos WP. MGMT: key node in the battle against genotoxicity, carcinogenicity and apoptosis induced by alkylating agents. DNA Repair (Amst). 2007; 6(8):1079-99.

6. Natsume A, Wakabayashi T, Ishii D, Maruta H, Fujii M, Shimato $S$, Ito $M$, Yoshida J. A combination of IFN-beta and temozolomide in human glioma xenograft models: implication of p53-mediated MGMT downregulation. Cancer Chemother Pharmacol. 2008;61(4):653-9.

7. Rosati SF, Williams RF, Nunnally LC, McGee MC, Sims TL, Tracey L, Zhou J, Fan M, Ng CY, Nathwani AC, Stewart CF, Pfeffer $L M$, Davidoff AM. IFN-beta sensitizes neuroblastoma to the antitumor activity of temozolomide by modulating $\mathrm{O}^{6}$-methylguanine DNA methyltransferase expression. Mol Cancer Ther. 2008;7(12):3852-8.

8. Zheng M, Bocangel D, Ramesh R, Ekmekcioglu S, Poindexter $N$, Grimm EA, Chada S. Interleukin-24 overcomes temozolomide resistance and enhances cell death by down-regulation of $\mathrm{O}^{6}$-methylguanine-DNA methyltransferase in human melanoma cells. Mol Cancer Ther. 2008;7(12):3842-51.

9. Cardozo AK, Kruhoffer M, Leeman R, Orntoft T, Eizirik DL. Identification of novel cytokine-induced genes in pancreatic betacells by high-density oligonucleotide arrays. Diabetes. 2001; 50 (5):909-20

10. Motomura K, Natsume A, Kishida Y, Higashi H, Kondo Y, Nakasu Y, Abe T, Namba H, Wakai K, Wakabayashi T. Benefits of interferon- $\beta$ and temozolomide combination therapy for newly diagnosed primary glioblastoma with the unmethylated $M G M T$ promoter: A multicenter study. Cancer. 2011;117(8):1721-30.

11. Shepherd J, Waugh N, Hewitson P. Combination therapy (interferon alfa and ribavirin) in the treatment of chronic hepatitis $C$ : a rapid and systematic review. Health Technol Assess. 2000;4 (33): $1-67$

12. Reznikov AG, Chaykovskaya LV, Polyakova LI, Kornelyuk AI, Grygorenko VN. Cooperative antitumor effect of endothelialmonocyte activating polypeptide II and flutamide on human prostate cancer xenografts. Exp Oncol. 2011;33(4):231-4.

13. Briegert M, Enk AH, Kaina B. Change in expression of MGMT during maturation of human monocytes into dendritic cells. DNA Repair (Amst). 2007;6(9):1255-63.

14. Lukash LL, Iatsyshyna AP, Kushniruk VO, Pidpala OV. Reprogramming of somatic cells of adults in vitro. Topics in experimental evolution of organisms. 2011; 11: 493-8.

15. Luchakivskaya Y, Kishchenko O, Gerasymenko I, Olevinskaya $Z$, Simonenko Y, Spivak M, Kuchuk M. High-level expression of human interferon alpha-2b in transgenic carrot (Daucus carota L.) plants. Plant Cell Rep. 2011;30(3):407-15.

16. Lukash LL. Cell therapy of heart pathologies. Biotekhnolohiia. 2008;1(1):40-5

17. Lylo VV, Matsevich LL, Kotsarenko EV, Babenko LA, Kornelyuk AI, Sukhorada EM, Lukash LL. Activation of gene expression of the $\mathrm{O}^{6}$-methylguanine-DNA-transferase repair enzyme upon the influence of EMAP II cytokine in human cells in vitro. Cytol Genet. 2011;45(6):373-8.
18. Morten JE, Margison GP. Increased $\mathrm{O}^{6}$-alkylguanine alkyltransferase activity in Chinese hamster V79 cells following selection with chloroethylating agents. Carcinogenesis. 1988;9(1):45-9.

19. Laemmli $U K$. Cleavage of structural proteins during the assembly of the head of bacteriophage T4. Nature. 1970;227(5259): 680-5.

20. Bradford $M M$. A rapid and sensitive method for the quantitation of microgram quantities of protein utilizing the principle of protein-dye binding. Anal Biochem. 1976;72:248-54.

21. Aldridge GM, Podrebarac DM, Greenough WT, Weiler IJ. The use of total protein stains as loading controls: an alternative to high-abundance single-protein controls in semi-quantitative immunoblotting. J Neurosci Methods. 2008;172(2):250-4.

22. Eaton SL, Roche SL, Llavero Hurtado M, Oldknow KJ, Farquharson $C$, Gillingwater TH, Wishart TM. Total protein analysis as a reliable loading control for quantitative fluorescent Western blotting. PLoS One. 2013;8(8):e72457.

23. Kotsarenko KV, Lylo VV, Macewicz LL, Babenko LA, Kornelyuk AI, Ruban TA, Lukash LL. Change in the MGMT gene expression under the influence of exogenous cytokines in human cells in vitro. Cytol Genet. 2013; 47(4):202-9.

24. Chen $Z$, Shen $D$, Wang J, Yang $Q$. Effect of interferon- $\alpha / \beta$ on temozolomide activity against MGMT-positive glioma stem-like cells in vitro and in vivo. J Clin Oncol. 2012;30 (suppl), e12503.

25. Lavon I, Fuchs D, Zrihan D, Efroni G, Zelikovitch B, Fellig Y, Siegal T. Novel mechanism whereby nuclear factor kappaB mediates DNA damage repair through regulation of $\mathrm{O}(6)$-methylguanine-DNA-methyltransferase. Cancer Res. 2007;67 (18):8952-9.

26. Macewicz LL, Kushniruk VO, Iatsyshyna AP, Kotsarenko KV, Lylo VV, Akopyan GR, Huleuk NL, Mykytenko DO, Lukash LL. Correlation of mutagenesis level with expression of reparative enzyme $\mathrm{O}^{6}$-methylguanine DNA methyltransferase during establishment of cell lines in vitro. Biopolym Cell. 2013;29 (6): 480-6.

27. Borodovsky A, Salmasi V, Turcan S, Fabius AW, Baia GS, Eberhart CG, Weingart JD, Gallia GL, Baylin SB, Chan TA, Riggins $G J$. 5-azacytidine reduces methylation, promotes differentiation and induces tumor regression in a patient-derived IDH1 mutant glioma xenograft. Oncotarget. 2013;4(10):1737-47.

28. Fenaux P, Mufti GJ, Hellstrom-Lindberg E, Santini V, Gattermann N, Germing U, Sanz G, List AF, Gore S, Seymour JF, Dombret H, Backstrom J, Zimmerman L, McKenzie D, Beach CL, Silverman LR. Azacitidine prolongs overall survival compared with conventional care regimens in elderly patients with low bone marrow blast count acute myeloid leukemia. J Clin Oncol. 2010;28(4):562-9.

29. Addeo R, Caraglia M, Bellini S, Abbruzzese A, Vincenzi B, Montella L, Miragliuolo A, Guarrasi R, Lanna M, Cennamo G, Faiola $V$, Del Prete $S$. Randomized phase III trial on gemcitabine versus mytomicin in recurrent superficial bladder cancer: evaluation of efficacy and tolerance. J Clin Oncol. 2010;28(4):543-8.

Received 07.09.13 